\title{
International Capital Flows
}

\section{When Safe Assets Scarcity Matters}

\author{
Ly Dai Hung* $\quad$ Nguyen Thi Thuy Hoan ${ }^{\dagger}$
}

July 2020

\begin{abstract}
In an open multi-country economy, the safe assets supply shapes the pattern of international capital flows. A higher productivity growth rate raises the net capital inflows for economies with abundant safe assets, but reduces the net capital inflows for economies with scarce safe assets. The cross-section analysis on a sample of 170 economies over 1980-2013 confirms the theory. The evidence is robust for instrument-variable (IV) analysis method.
\end{abstract}

Keywords: International Capital Flows, Safe Assets, Public Debts. JEL Classifications: F15, F36, F43.

*Email: hunglydai@gmail.com. VNU International School, Vietnam National University, Hanoi, Vietnam. Vietnam Economic Commission, Hanoi, Vietnam. Thang Long Institute of Mathematics and Applied Sciences (TIMAS), Hanoi, Vietnam. This research is funded by Vietnam National Foundation for Science and Technology Development (NAFOSTED) under grant number 502.01-2020.17.

$\dagger$ Email: hoan.ntt89@gmail.com. State Securities Commission of Vietnam, Hanoi, Vietnam. Address: 234 Luong The Vinh street, Nam Tu Liem district, Ha Noi city, Viet Nam. 


\section{Introduction}

The financial globalization for recent decades is characterized by two key features. Feature 1: the pattern of international capital flows diverges from the prediction by economic growth theory. The neoclassical growth model (Solow (1956)) implies that the capital should flow from rich economy with huge capital stock to poor economy with low capital stock or from the slow-growing economy to fast-growing economy. The reason is that the economy with low capital stock or high growth rate has a high marginal product of capital (Hung (2020) ), which attracts the net capital inflows. The data, however, shows that capital does not flow from rich to poor economy $($ Lucas $(1990))$. And the capital also tends to flow from the developing ith high growth rate to advanced economies with low growth rate, a phenomenon labeled as up-hill capital flows (Prasad, Rajan, and Subramanian (2007)).

Feature 2: the safe assets are scarce on the world capital market. This type of assets includes uncertainty-insensitive assets Caballero, Farhi and Gourinchas (2016)) or information-insensitive assets (Dang, Gorton, Holmström and Ordonez (2017)). Their supply, mainly by some advanced economies, does not meet their demand backed by huge savings by emerging economies. As a result, the world interest rate tends to be persistently low (Blanchard (2019) ), and even the world economy is at risk of financial crisis (Bernanke, Bertaut, Demarco and Kamin (2011)).

Despite extensive debates on the determinants and impact of each phenomenon on the global economy, there are very few formal analysis to 
account for these two joint phenomena. This constitutes a research gap in the literature.

We fill in the gap by combining theory with evidence to investigate the pattern of international capital flows (Feature 1), on accounting for the scarcity of safe assets (Feature 2). In particular, we construct an open overlapping generations (OLG) multi-country economy with different safe assets supply across countries. The model analyzes the role of safe assets supply on shaping the pattern of capital flows. Then, we employ a crosssection regression on a sample of 180 economies over period 1980-2013. The large sample covers both developing and advanced economies while the long period looks at long-run difference in growth with a fair degree of capital mobility. Then, the evidence examines consistency between the theory and the data.

We show that the pattern of international capital flows depends on the safe assets supply. Within our model, the interest rate depends on both the productivity growth and safe assets supply. Then, an economy with high productivity growth can have high interest rate only when it also has huge safe assets supply. Since the capital flows from economies with low interest rate to economies with high interest rate, the difference on the supply of safe assets determines the pattern of cross-border capital flows. For economies with abundant safe assets (its assets supply being huger than world average one), an increase of productivity growth raises the net total capital inflows. For economies with scarce safe assets, however, a higher productivity growth reduces the net capital inflows. Therefore, the safe assets supply is a key driver of cross-border capital flows. 
The paper belongs to the literature on the cross-border capital flows (see Gourinchas and Rey (2014) for a recent survey). Alfaro, KalemliOzcan and Volosovych (2014) show that the pattern of capital flows follows the prediction by the neoclassical growth model. For a sample of both advanced and developing economies over 1980-2013, a higher growth rate of output per capita, a measure of productivity growth rate, raises the net capital inflows. Recently, Byrne and Fiess (2016) provide a similar result that the economic growth, beside financial opennes and institutional quality, is driving the net capital inflows. Gourinchas and Jeanne [ (2013) ), however, document an allocation puzzle: the economy growing faster tends to receive less capital inflows. Sandri (2014) explains this phenomenon by finding that under uninsurable investment risk, the entrepreneurs have to reply on self-financing. When the productivity growth accelerates, they need to increase saving to finance new investment. If the savings raise more than investment, the accelerations of growth is associated with the outflows of capitals. Recently, Hung (2019) builds a theory to prove that both the prediction by neoclassical growth model and the allocation puzzle hold, depending on the interaction of financial frictions and productivity growth rate.

Our paper solves the controversy on the pattern of capital flows. For an open economy, when its safe assets supply is high, the net total capital inflows are increasing on the productivity growth. Thus, the prediction of neoclassical growth model only holds for economies with abundant safe assets supply. When the economy has low safe assets supply, the net total capital inflows are decreasing on the productivity growth. Then, 
the allocation puzzle applies for economies with scarce safe assets supply. Therefore, both the neoclassical growth model and allocation puzzle holds, depending on the safe assets supply.

The current paper is closedly related to the literature on the safe assets on financial globalization. Maurizio, Stracca and Venditti (2019) employ a sample of monthly changes in government bond yields in 40 advanced and emerging countries to investigate the fundamentals of safe assets. They show that the external sustainability is important for emerging markets, particularly after the global financial crisis. Recently, by both a theoretical model and empirical evidence, Hung and Hoan (2020) show that the accumulation of foreign safe assets for risk-sharing motivation can lead to the outflows of capital at the economy having positive productivity shocks. These papers, however, do not account for the interaction between safe assets and international capital flows, which is focal point in our paper. This interaction is proved to be important for the macroeconomic stability Bernanke, Bertaut, Demarco and Kamin (2011).

Recently, Caballero, Farhi and Gourinchas (2016) show that the scarcity of safe assets can generate a safety trap, defined as a type of liquidity trap. If the world economy suffers from the scare safe assets supply, the secular stagnation can spread from an economy to other via capital flows. Thus, the safe assets scarcity can lead to the world secular stagnation. For a small open economy model of Japan, Sakuragawa and Sakuragawa (2016) show that the absence of safe assets explains the mechanism under which the low interest rate coexists with government's large outstanding debt. With a low supply of safe assets, the interest rate 
is insensitive to any change in fiscal conditions and does not fully reflect the risk premium.

While their paper separates the safe assets supply and capital flows, our paper focuses on the interaction between these two macroeconomic variables. Given the productivity growth rate, the capital flows from the economies with low supply of safe assets to the economies with high supply of safe assets. Therefore, the net capital inflows is driven by the supply of safe assets.

Our paper also makes contribution on the literature on the role of public debts on the capital accumulation. Woodford (1990) shows that the public debts contribute on the domestic capital accumulation since firms accumulate the debts to transfer income over time. The model is a closed economy and the role of debts on capital accumulation only works under binding credit constraint for firms. Our paper, however, considers the safety aspect of public debt in an open multi-country economy without the credit constraint. The public debt still contributes on the capital accumulation since its safety attracts the capital from foreign households, who are seeking a store of wealth. Therefore, the safety of public debts is also important for the domestic capital accumulation.

Recently, Kumar and Woo (2010) show that, on a panel of advanced and emerging economies over almost four decades, a higher initial debt per GDP ratio is associated with a reduction of investment, then, a slower growth of capital stock. Their analysis, however, does not take into account the complementary between foreign and domestic capital. Our evidence shows that a huger public debt stock can raise the inflows of 
foreign capital. And this contributes positively on the domestic capital accumulation.

The paper is structured as follows. After the introduction, section (2) lays out the model, characterizes the equilibrium, and presents the pattern of international capital flows. Then, section (3) shows the empirical framework and associated evidence on the interaction between safe assets supply and international capital flows. Finally, section (4) concludes.

\section{Theory}

The model includes many large countries, each is denoted by $(j)$. Each country is populated with overlapping generations of households. Each household lives for two periods and supplies one unit of labor when young and retires when old. Other features of model are standard. Preferences have the same structure and parameter values across countries. The good is used for consumption and investment and is traded freely and costlessly. Capital is freely mobile, but labor is immobile across countries.

\subsection{Economy}

In each country $(j)$, let $c_{t}^{y}$ and $c_{t+1}^{o}$ denote the consumption of an agent when young and old, respectively. The lifetime utility of an agent born in period $t$ is:

$$
U_{t}=u\left(c_{t}^{y}\right)+\beta u\left(c_{t+1}^{o}\right)
$$


Preferences follow a constant-relative-risk-aversion (CRRA) function $u(c)=\frac{c^{(1-1 / \sigma)}-1}{1-1 / \sigma}$ with an inter-temporal coefficient of substitution $(\sigma>$ $1)$. Note that pattern of capital flows does not depend on value of $(\sigma)$.

When young, each individual receives an exogenous endowment $\left(w_{t}\right)$. She allocates her endowment between consumption and saving $\left(s_{t}^{y}\right)$. When old, she receives the interest rate $\left(R_{t+1}\right)$ on her savings. In details, the budget constraints are as following:

$$
\begin{aligned}
c_{t}^{y}+s_{t}^{y} & =w_{t} \\
c_{t+1}^{o} & =R_{t+1} s_{t}^{y}
\end{aligned}
$$

The Euler equation, and associated saving rate is as following:

$$
\begin{aligned}
u^{\prime}\left(c_{t}^{y}\right) & =\beta R_{t+1} u^{\prime}\left(c_{t+1}^{o}\right) \\
s_{t}^{y} & =\frac{1}{1+\beta^{-\sigma} R_{t+1}^{(1-\sigma)}} w_{t}
\end{aligned}
$$

At the time period $(t)$, the economy $(j)$ has an exogenous supply of financial safe assets, denoted by $B_{t}$. We define the output as $Y_{t}=N_{t} w_{t}$, and assume that the output grows with exogenous rate $\left(g_{t}^{y}\right)$ so that: $Y_{t}=$ $\left(1+g_{t}^{y}\right) Y_{t-1}$. Then, we also define the assets-output ratio $\left(b_{t}^{j}\right)$ as:

$$
b_{t}^{j}=\frac{B_{t}^{j}}{Y_{t}^{j}}
$$

Moreover, we also assume that at steady state, the assets-output ratio is constant: $b_{t}=b, \forall t$.

The model is constructed to explore the interaction of safe assets supply and international capital flows. First, the lack of uncertainty is appropriate to focus on the safe assets, since this type of assets only provides 
a constant rate of return. Second, the supply of safe assets is exogenous. This exogeneity keeps model to be parsimonious and tractable. Recently, Farhi, Caballero and Gourinchas (2008) also employ these two features to construct a model of global imbalances, based on the interaction between financial assets supply and capital flows.

\subsection{Equilibrium}

At autarky economy, the capital is immobile across countries. Then, each country has its own interest rate. The aggregate savings $\left(N_{t} s_{t}^{y}\right)$ raise the demand for financial assets. By market clearing condition, the demand is equal to the supply of assets: $N_{t} s_{t}^{y}=B_{t}$. By using (11) and (2), this condition gives the autarky interest rate $\left(R_{t+1}\right)$.

$$
R_{t+1}=\left(\frac{1}{b_{t}}-1\right)^{1 /(1-\sigma)} \beta^{\sigma /(1-\sigma)}
$$

At integration economy, the free mobility of capital implies a common world interest rate: $R_{t}^{j}=R_{t}^{w}, \forall j$. Moreover, the world total demand must be equal to the world total supply of financial assets: $\Sigma_{j} N_{t}^{j} s_{t}^{y, j}=\Sigma_{j} B_{t}^{j}$. This integration market clearing condition, combined with (1) and (2), gives the integration interest rate.

$$
R_{t+1}^{w}=\left(\frac{1}{\bar{b}_{t}}-1\right)^{1 /(1-\sigma)} \beta^{\sigma /(1-\sigma)}
$$

whereby, the world average assets-output ratio is: $\bar{b}_{t}=\Sigma_{j} \frac{Y_{t}^{j}}{\Sigma_{j} Y_{t}^{j}} b_{t}^{j}$.

The world interest rate at the integration steady state lies between the lowest and highest autarky steady-state interest rate.

$$
\min _{b^{j}} R\left(b^{j}\right)<R^{w}<\max _{b^{j}} R\left(b^{j}\right)
$$


At integration, the capital would flow from the economy with low autarky interest rate to the one with high autarky interest rate until the interest rate is the same across countries. We employ this principle to analyze the pattern of international capital flows in the next section.

\subsection{International Capital Flows}

In each country $(j)$, the current-period savings stock, $S_{t}=N_{t} s_{t}^{y}$, is allocated into next-period net foreign assets accumulation $\left(N F A_{t+1}\right)$ and domestic financial assets $\left(B_{t}\right): S_{t}=N F A_{t+1}+B_{t}$. Thus, the net foreign assets per output ratio is:

$$
\frac{N F A_{t+1}}{Y_{t+1}}=\left(\frac{S_{t}}{Y_{t}}-\frac{B_{t}}{Y_{t}}\right) \frac{Y_{t}}{Y_{t+1}}
$$

By replacing the world interest rate into the saving rate (1), we have:

$$
\frac{S_{t}}{Y_{t}}=\frac{1}{1+\beta^{-\sigma} R^{w}{ }_{t+1}^{(1-\sigma)}}
$$

At steady state, by assumption, the net output growth rate is constant: $g_{t}^{y}=g^{y}, \forall t$, and the assets-output ratio is constant: $b_{t}=b, \forall t$. Thus, the world interest rate (3) is constant at steady state: $R_{t}^{w}=R^{w}, \forall t$. Note that the interest rate is an endogenous variable which clears the capital market. In the OLG model, the return on the past savings are paid from the current savings. At steady state, savings grow with the output growth rate $(g)$ while the bond repayment grows with the net interest rate $r \equiv(R-1)$. While

$(g)$ is exogenous, $(r)$ adjusts endogenously to ensure the equality $(g=r)$.

Then, the net foreign assets per output ratio is also constant.

$$
\frac{N F A}{Y}=\frac{1}{\left(1+g^{y}\right)}\left[\frac{1}{1+\beta^{-\sigma} R^{w(1-\sigma)}}-b\right]
$$


By evaluating the world interest rate (3) at steady state, then, plugging the result into the last equation, we have:

$$
\frac{N F A}{Y}=\frac{(\bar{b}-b)}{\left(1+g^{y}\right)}
$$

The current account at end of period $(t)$ is measured by the change of net foreign assets:

$$
C A_{t}=N F A_{t+1}-N F A_{t} \Rightarrow \frac{C A_{t}}{Y_{t}}=\frac{N F A_{t+1}}{Y_{t+1}} \frac{Y_{t+1}}{Y_{t}}-\frac{N F A_{t}}{Y_{t}}
$$

At steady state, with a constant ratio of net foreign assets over output (4), the current account per output ratio is also constant.

$$
\frac{C A}{Y}=g^{y} \frac{N F A}{Y}
$$

The net total capital inflows are measured as the negative value of current account. Plugging (4) into (5), they are as following:

$$
-\frac{C A}{Y}=g^{y}\left(-\frac{N F A}{Y}\right)=\frac{g^{y}}{\left(1+g^{y}\right)}(b-\bar{b})
$$

The result implies that an economy, with higher supply of safe assets than the world, will have positive net total capital inflows.

$$
-\frac{C A}{Y}>0 \Leftrightarrow b>\bar{b}
$$

The supply of safe assets also determines the impact of economic growth on the net total capital inflows. The result is summarized on the following proposition.

Proposition 2.3.1. The pattern of international capital flows depends on the supply of safe assets.

$$
\frac{\partial(-C A / Y)}{\partial\left(1+g^{y}\right)}>0 \Leftrightarrow b>\bar{b}
$$


Proof. Taking derivative of the net total capital inflows (6), we have:

$$
\frac{\partial(-C A / Y)}{\partial\left(1+g^{y}\right)}=\frac{(b-\bar{b})}{\left(1+g^{y}\right)^{2}}>0 \Leftrightarrow b>\bar{b}
$$

The result sheds a new light on the impact of economic growth on the net total capital inflows. For an economy, an increase of growth leads to more inflows of capital, as implied by Neo-Classical growth model, only when its safe assets supply is higher than the world averaged supply. The increase of growth, however, can reduce the inflows of capital, when the economy has a lower safe assets supply than the rest of world. Therefore, the supply of safe assets shapes the pattern of international capital flows.

Note that the pattern of capital flows does not depend on the intertemporal substitution coefficient $(\sigma)$. At integration, the interest rate is equalized across countries, then, the saving rate is the same across countries, not depending on the value of $\sigma$.

\section{Evidence}

\subsection{Framework}

\section{Data}

Each variable is computed yearly, then averaged over the period 1980-2013 to form a cross-section sample. The net total capital inflows (negCA2yt) are measured as the negative value of the current account per output ratio 
in percentage terms, which is from the dataset on net private and public capital flows constructed by Alfaro, Kalemli-Ozcan and Volosovych (2014). This panel includes a number of countries, both developing and advanced, and spans the period from 1980 to 2013 .

The gross productivity growth rate (GDPpcgrowt $\left.h_{t}\right)$ is measured by the gross growth of output per capita. In neoclassical growth model $($ Solow $(1956))$, the long-run growth rate of per capita output is equal to the total factor productivity growth rate. Data is explored from World Development Indicators.

Currently, there is not a world database on the supply of safe assets. To overcome this problem, we consider a proxy variable for the safe assets, which also has an available cross-country database. By definition, the safe assets include all uncertainty-insensitive assets, with a constant rate of return in all realized states of nature. Recently, Caballero, Farhi and Gourinchas (2016) employ this concept to analyze the safe assets scarcity on the spread of recession from one economy to the other via capital flows. According to this definition, public debts are classified as safe assets $(\mathrm{He}$, Krishnamurthy and Milbradt (2019); Farhi and Maggiori (2017))). For the data, the supply of public debts is measured by the central government gross debt stock per GDP, denoted by $(a c g)$. The variable covers all debt instruments owed by central government: loans; debt securities; currency and deposits; insurance, pension, and standardized guarantee schemes; other accounts payable; and special drawing rights. The data is extracted from the Global Debt Database (GDD), constructed by Mbaye, Badia and Chae (2018). This database of International Monetary Fund (IMF) 
comprises total gross debt of the nonfinancial sector for 190 economies, including advanced economies, emerging market economies and low-income countries, from 1950 to 2017.

We also carry out regression with instrument variable. This method addresses the potential endogeneity between the net total capital inflows and productivity growth. We collect the share of high-technology exports over total manufacturing exports as an instrument variable for the productivity growth rate. This variable passes the test of validity of instrument variable. The data is from the World Development Indicators.

\section{Table 1: DESCRIPTIVE STATISTICS}

\begin{tabular}{lccccc}
\hline \hline Variables & Obs & Mean & Std. Dev. & Min & Max \\
\hline \hline Net total capital inflows (\%) (anegCA2y) & 142 & 3.526994 & 5.24884 & -13.81684 & 15.72594 \\
Per capita output growth rate (\%) (aGDPpcgrowth) & 142 & 2.124713 & 1.465987 & -1.026358 & 6.334434 \\
Supply of public safe assets per GDP (\%) (acg) & 130 & 46.6569 & 28.98779 & 3.872267 & 170.4659 \\
High-technology export per manufacturing exports (\%) (ahitech) & 120 & 9.262189 & 9.022054 & .0776136 & 48.65068 \\
\hline
\end{tabular}

Table 1 reports the descriptive statistics on the cross-section sample. The net total capital inflows have a mean of $3.5 \%$ with a standard deviation of $5.24 \%$. Compared with this variable, the per capita output growth rate has a lower mean $2.12 \%$ and a lower standard deviation $1.46 \%$, while the supply of safe assets has both a higher mean of $46.6 \%$ and a larger standard deviation of $28.9 \%$. Other variables also exert large standard deviation around their mean values. Thus, the data set offers rich variation for exploring the pattern of capital flows.

\section{Model}

The Proposition (2.3.1) implies a regression model with threshold. In 
details, only when an economy's supply of safe assets is greater than the world average one, its net total capital inflows are increasing on the productivity growth rate. Therefore, the world average supply of safe assets constitutes a threshold, which separates two different patterns of international capital flows.

In order to examine this theoretical result on data, we define $d^{j}$ as a dummy variable: $d^{j}=0$ for $b^{j}<\bar{b}$, and $d^{j}=1$ for $b^{j}>\bar{b}$, whereby $\bar{b}$ is the world average supply of safe assets. By construction, the benchmark group illustrates the economy with the scarcity of safe assets. And the group of economies with the abundance of safe assets is compared against the benchmark group. The empirical model is as following:

$$
\text { anegC } A 2 y^{j}=\alpha+\beta . a G D P \text { Pcgrowth } h^{j}+\gamma . a G D P \text { Pcgrowth } h^{j} . d^{j}+u^{j}
$$

The value of coefficient $(\beta)$ measures the dependence pattern of net total capital inflows on the productivity growth rate. And the value of coefficient $(\gamma)$ illustrates the role of safe assets supply on shaping the pattern of capital flows. If $(\beta<0, \gamma>0,|\gamma|>|\beta|)$, a higher productivity growth rate raises the net capital inflows for economy with abundant safe assets, but reduces the net capital inflows for economy with scarce safe assets. On that case, we confirm the theoretical result implied by the Proposition 2.3.1.

\subsection{Ordinary Least Square Results}

Table (2) reports the regression of net total capital inflows on the supply of safe assets and productivity growth rate. In column 1, an 1\% increase 
of safe assets supply raises the net capital inflows by $0.06 \%$. Thus, the net total capital inflows are increasing on the safe assets supply. This result is underlined by the steady-state net capital inflows $(6)$. Since a higher safe assets supply raises the autarky interest rate, it leads to more net capital inflows. In column 2 , an $1 \%$ increase of productivity growth rate reduces the net capital inflows by $0.56 \%$. This result is consistent to the well-known up-hill capital flows pattern (Prasad, Rajan, and Subramanian (2007), Gourinchas and Jeanne (2013)): neoclassical growth model predicts that the net capital inflows are increasing on the productivity growth, but the reversed patterns holds in the data.

The third column examines the role of safe assets supply as key determinant of international capital flows pattern. In particular, the interaction term of productivity growth and safe assets supply has a positive value: $\gamma=1.18$. And its absolute value is higher that the absolute value of productivity growth rate: $\gamma=1.18>\beta=-0.9$. Thus, the net total capital inflows are only increasing when the safe assets supply is greater than its world average value.

$$
\frac{\text { DanegCA2y }}{\partial a G D P \text { pcgrowth }}=-0.9 \quad \text { for economies with scarce safe assets }(d=0)
$$

$$
\frac{\partial a n e g C A 2 y}{\partial a G D P \text { Pcgrowth }}=0.28 \text { for economies with abundant safe assets }(d=1)
$$

In brief, the result confirms the Proposition 2.3.1) that the supply of safe assets shapes the dependence pattern of international capital flows. 
Table 2: Regression Results of Net Total Capital Inflows on Productivity Growth Rate and Safe Assets Supply

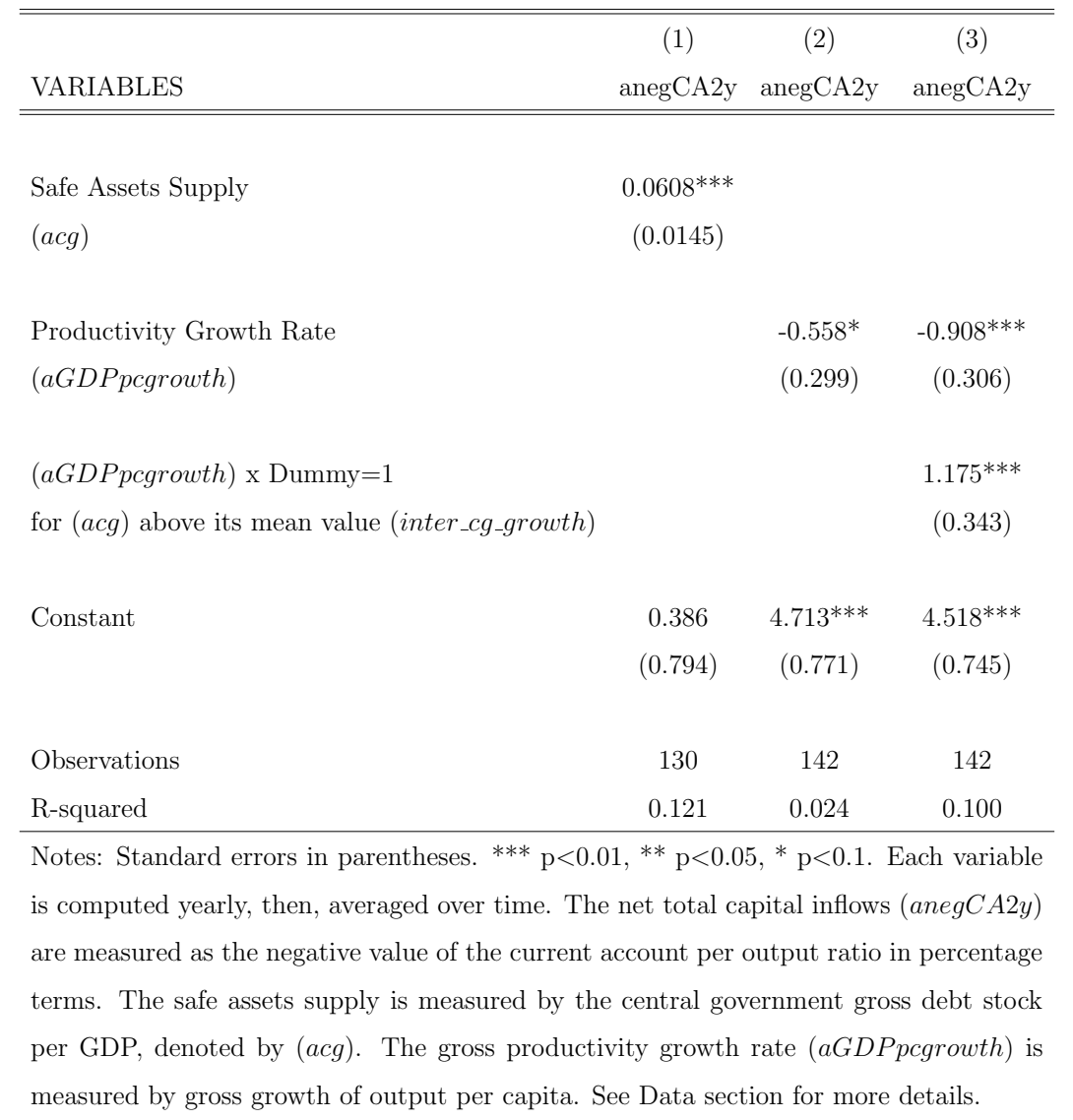

Figure (1) illustrates the empirical evidence on the pattern of international capital flows. On Panel A, for economies with assets scarcity, the net total capital inflows are decreasing on the productivity growth. The slope of curve is -0.9. On Panel B, for economies with assets abundance, the net capital inflows are increasing on the productivity growth. The slope of curve is 0.28 . Thus, the world average supply of safe assets separates two different patterns of international capital flows: the allocation puzzle for scarce safe assets and the prediction of neoclassical growth model for abundant safe assets. 
Figure 1: Pattern of International Capital Flows

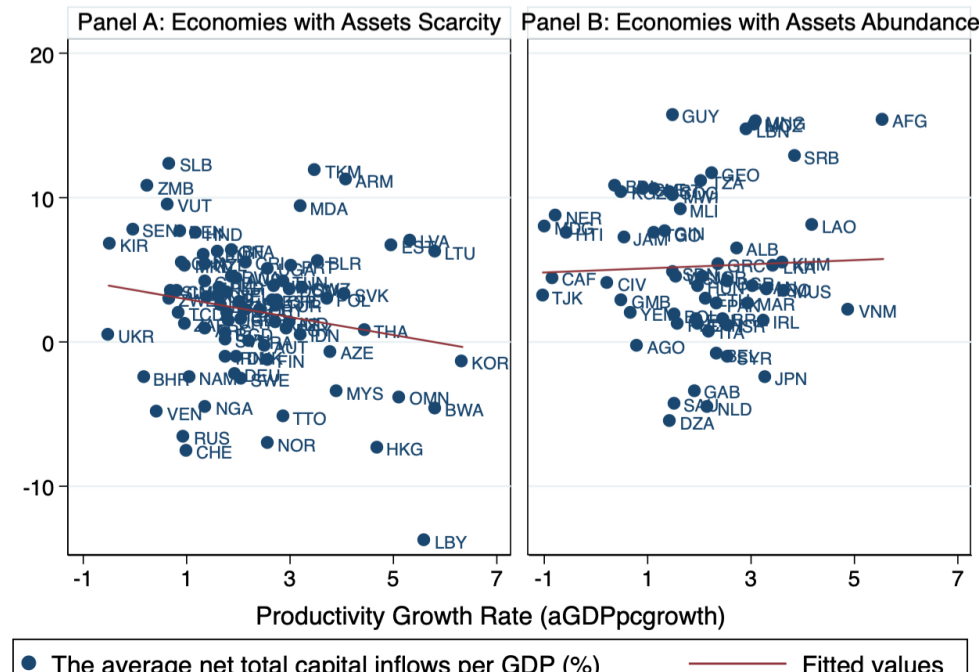

\subsection{Instrument Variable Results}

Table (3) shows the IV regression results of net total capital inflows on the productivity growth rate and safe assets supply. The productivity growth rate is instrumented by the high-technology export as percentage of manufacturing exports. This variable satisfied the requirement of an instrument variable: it affects the productivity growth rate by technology transfer from the export sector to other sector within economy and does not influence the net total capital inflows. On column 1, the net total capital inflows are decreasing on the productivity growth rate. On column 2 , the coefficient of interaction term between productivity growth rate and dummy variable is positive. Therefore, the evidence supports the cross-sectional result that the safe assets supply can shape the pattern of international capital flows. 
Table 3: IV Regression Results of Net Total Capital Inflows on Productivity Growth Rate and Safe Assets Supply: Productivity Growth Rate is instrumented by High-Technology Exports as Percentage of Manufactured Exports

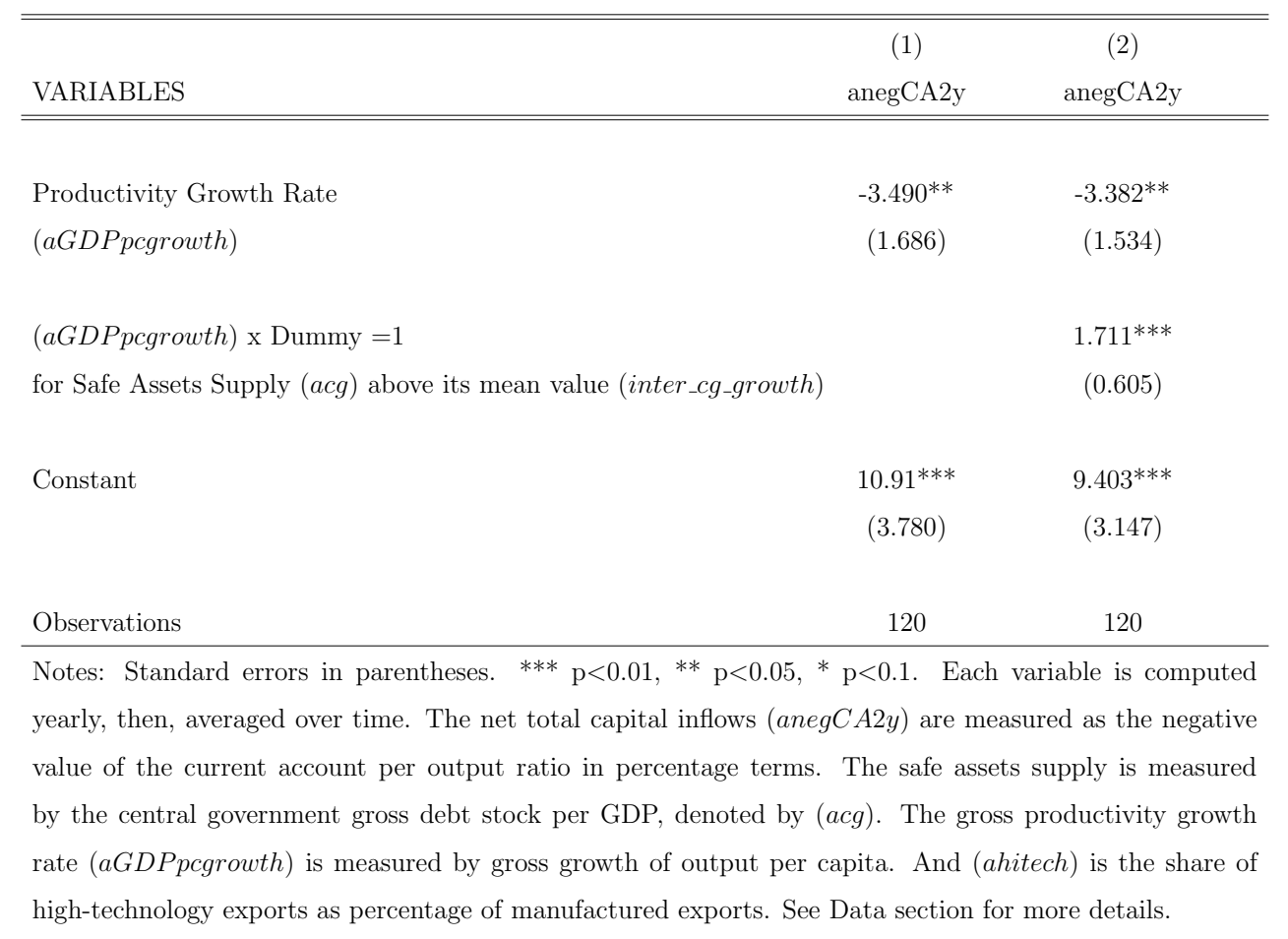

Table (4) shows the results of the two stage least squares regression in Panel A, the associated first stage regression in Panel B, and the OLS counterpart in Panel C. In Panel A, when the productivity growth rate is instrumented by share of high-technology exports over manufacturing exports, the coefficient of productivity growth is negative while that of interaction term between the growth rate and dummy variable is positive. Thus, the safe assets supply affects the pattern of international capital flows. In Panel B, the first stage regression shows that the productivity growth rate is positively affected by the share of high-tech export 
over manufacturing export, with $R^{2}=0.06$. Moreover, the estimated coefficient by two-stage least squares in Panel A is higher than the OLS counterpart shown in Panel C. Since the IV regression corrects for both endogeneity and attenuation bias caused by measurement error, the result suggests that the reverse causality is less serious than the measurement error.

Table 4: Steps of IV Regression of Net Total Capital Inflows on Productivity Growth and Safe Assets Supply: Productivity Growth is instrumented by High-Technology Exports as Percentage of Manufactured Exports

\begin{tabular}{|c|c|}
\hline \multicolumn{2}{|c|}{ Panel A: Two-Stage Least Squares for Net Total Capital Inflows } \\
\hline Productivity Growth Rate & $-3.382^{* *}$ \\
\hline (aGDPpcgrowth) & $(1.534)$ \\
\hline$($ aGDPpcgrowth $) \times$ Dummy $=1$ & $1.711^{* * *}$ \\
\hline for Safe Assets Supply (acg) above its mean value (inter_cg_growth) & $(0.605)$ \\
\hline \multicolumn{2}{|c|}{ Panel B: First Stage for Productivity Growth Rate } \\
\hline High-Technology Exports Percentage & $0.0378 * * *$ \\
\hline of Manufacturing Exports (ahitech) & $(0.0136)$ \\
\hline R-squared & 0.061 \\
\hline \multicolumn{2}{|c|}{ Panel C: Ordinary Least Squares for Net Total Capital Inflows } \\
\hline Productivity Growth Rate & $-0.908^{* * *}$ \\
\hline (aGDPpcgrowth) & $(0.306)$ \\
\hline$(a G D P p c g r o w t h) \times$ Dummy $=1$ & $1.175^{* * *}$ \\
\hline for Safe Assets Supply (acg) above its mean value (inter_cg_growth) & $(0.343)$ \\
\hline Countries & 142 \\
\hline \multicolumn{2}{|c|}{$\begin{array}{l}\text { Notes: Panel A reports the two-stage least-squares estimates, instrumenting for productivity growth rate using share of } \\
\text { high-technology exports over manufacturing exports; Panel B reports the corresponding first stage. Panel } \mathrm{C} \text { reports the } \\
\text { coefficient from an OLS regression of the dependent variable against productivity growth rate and safe assets supply. } \\
\text { All regressions include a constant. Standard errors in parentheses. }{ }^{* * *} \mathrm{p}<0.01,{ }^{* *} \mathrm{p}<0.05,{ }^{*} \mathrm{p}<0.1 \text {. Each variable is } \\
\text { computed yearly, then, averaged over time. The net total capital inflows }(\text { anegCA2y) are measured as the negative value } \\
\text { of the current account per output ratio in percentage terms. The safe assets supply is measured by the central government } \\
\text { gross debt stock per GDP, denoted by (acg). The gross productivity growth rate (aGDPpcgrowth) is measured by gross } \\
\text { growth of output per capita. And (ahitech) is the share of high-technology exports as percentage of manufactured }\end{array}$} \\
\hline
\end{tabular}




\section{Conclusion}

We construct an OLG multi-country open economy to show that the supply of safe assets determines the pattern of international capital flows. For one economy, the net total capital inflows are increasing on the productivity growth rate only for its safe assets supply is higher than the world average one. The evidence on a cross-section sample of 170 economies supports the theory.

The result provides important policy implication. The supply of safe assets needs to be raised so that the economy can receive more capital inflows for an improvement of productivity growth rate. Thus, the policy to stimulate the economic growth needs to be equipped with a policy to upgrade the manufacturing capacity of safe assets.

For future research avenue, the theory can be extended to account for the uncertainty. With both safe and risky financial assets, the net capital inflows can be decomposed into safe and risky assets flows, such as portfolio equities and foreign direct investment capital flows. Another direction can account for sovereign insolvency which can break the equilibrium with self fulfilling expectations.

\section{References}

\section{Alfaro, Laura, Sebnem KalemliOzcan, and Vadym Volosovych.}

"Sovereigns, upstream capital flows, and global imbalances." Journal of the European Economic Association 12.5 (2014): 1240-1284. 
Blanchard, Olivier. "Public debt and low interest rates." American Economic Review 109.4 (2019): 1197-1229.

Byrne, Joseph P., and Norbert Fiess. "International capital flows to emerging markets: National and global determinants." Journal of International Money and Finance 61 (2016): 82-100.

Bernanke, Ben S., Carol C. Bertaut, Laurie Demarco, and Steven B. Kamin. "International capital flows and the return to safe assets in the united states, 2003-2007." FRB International Finance Discussion Paper 1014 (2011).

Caballero, Ricardo J., Emmanuel Farhi, and Pierre-Olivier Gourinchas. "Safe asset scarcity and aggregate demand." American Economic Review 106.5 (2016): 513-18.

Dang, T. V., Gorton, G., Holmström, B., and Ordonez, G. (2017). Banks as secret keepers. American Economic Review, 107(4), 1005-29.

Dai Hung, Ly, and Hoan Nguyen Thi Thuy. "International capital flows in club of convergence." Journal of Economic Studies (2020).

Farhi, Emmanuel, Ricardo Caballero, and Pierre-Olivier Gourinchas. "An Equilibrium Model of Global Imbalances and Low Interest Rates." American Economic Review 98.1 (2008).

Farhi, Emmanuel, and Matteo Maggiori. "A model of the interna- 
tional monetary system." The Quarterly Journal of Economics 133.1 (2017): 295-355.

Gourinchas, Pierre-Olivier, and Olivier Jeanne. "Capital flows to developing countries: The allocation puzzle." The Review of Economic Studies (2013): rdt004.

Gourinchas, Pierre-Olivier, and Hlne Rey. "External adjustment, global imbalances, valuation effects." Handbook of international economics. Vol. 4. Elsevier, 2014. 585-645.

He, Zhiguo, Arvind Krishnamurthy, and Konstantin Milbradt. "A model of safe asset determination." American Economic Review 109.4 (2019): 1230-62.

Hung, Ly-Dai. "Non-linear pattern of international capital flows." Review of World Economics 155.3 (2019): 575-600.

Hung, Ly-Dai. "Empirics for marginal product of capital." Journal of International Commerce, Economics and Policy 11.01 (2020): 2050003.

Kumar, Manmohan, and Jaejoon Woo. "Public debt and growth." IMF working papers (2010): 1-47.

Lucas, Robert E. "Why doesn't capital flow from rich to poor countries?." The American Economic Review 80.2 (1990): 92-96.

Maurizio Michael Habib, Livio Stracca, and Fabrizio Venditti (2019). "The fundamentals of safe assets". Journal of International Money and Finance, December 2019, 102119. 
Mbaye, Samba, Ms Marialuz Moreno Badia, and Kyungla Chae. Global debt database: Methodology and sources. International Monetary Fund, 2018.

Prasad, Eswar S., Raghuram G. Rajan, and Arvind Subramanian. Foreign capital and economic growth. No. w13619. National Bureau of Economic Research, 2007.

Sandri, Damiano. "Growth and capital flows with risky entrepreneurship." American Economic Journal: Macroeconomics 6.3 (2014): 10223.

Sakuragawa, Masaya, and Yukie Sakuragawa. "Absence of safe assets and fiscal crisis." Journal of the Japanese and International Economies 40 (2016): 59-76.

Solow, Robert M. "A contribution to the theory of economic growth." The quarterly journal of economics 70.1 (1956): 65-94.

Woodford, Michael. "Public Debt as Private Liquidity." American Economic Review 80.2 (1990): 382-388. 